Hydrology and Earth System Sciences, 8(3), 521-532 (2004) C EGU

\title{
The water quality functioning of the upper River Severn, Plynlimon, mid-Wales: issues of monitoring, process understanding and forestry
}

\author{
Colin Neal \\ Centre for Ecology and Hydrology, Crowmarsh Gifford, Wallingford, OXON, OX10 8BB, UK \\ Email: cn@ceh.ac.uk
}

\begin{abstract}
An overview of hydrochemical studies of the upper River Severn catchment in the Plynlimon region of mid-Wales, as linked to twenty years of research at CEH Wallingford, is presented. The work provides a bibliography of publications to date and illustrates that the water quality changes associated with felling are often small when compared with the effects of climate variability. The felling effects are manifested most clearly at the local scale and with clear as opposed to phased felling. Phased felling over several years, which is standard forestry practice, provides a much reduced response. The highly heterogeneous nature of the catchment is emphasised. This complexity makes identification and modelling of the changes very difficult to describe in terms of space and time. Long-term records (forty years or more) are needed to allow assessment of the changing water quality patterns associated with climate variability, climate change, changing pollutant deposition patterns and forestry rotation cycles. More detailed but still long-term (daily to sub-daily) records are required to examine "fractal processes": within the fine structure is a high information content that can help unravel the dynamics of the internal workings of the catchment in a way that experiments at the plot scale cannot resolve.
\end{abstract}

Keywords: nutrients, acidity, trace metals, trace elements, Plynlimon, River Severn, forestry, fractals

\section{Introduction}

Water quality and quantity issues linked to forestry rotation cycles have been important for the last forty or more years for the UK uplands following the intensive introduction of conifer plantations between the First and Second World Wars in response to the strategic need for a sustained timber resource (Hudson et al., 1997a; Neal, 1997a). In this context, the Plynlimon experimental catchments of the then Institute of Hydrology (now Centre for Ecology and Hydrology, CEH) were instigated as a comparative study in the 1960 s. This was done to examine the functioning and hydrological balance of upland moorland and conifer plantation catchment systems in the UK (McCulloch, 1970, 1997; McCulloch and Robinson, 1993; Newson, 1985; Hudson et al., 1997a,b). The Plynlimon catchments are the source areas of two of the major UK rivers, the Wye and the Severn, the former representing semi-natural moorland and the latter including conifer afforested moorland, the Hafren Forest. Later, the work was extended to include chemistry and biology. This extension began with initiatives in the late 1970s by the then Institute of Terrestrial Ecology at Bangor (Reynolds, 1983, 1984; Hornung et al., 1985, 1986a,b; Reynolds et al., 1988, 1992, 1997a,b) and in 1983 by the then Institute of Hydrology (Neal et al., 1986, 1997a,b,c, 2001). These organisations are now the Centre for Ecology and Hydrology (CEH) Bangor and Wallingford, respectively. The remit for such studies was to examine element cycling in semi-natural upland ecosystems including the effects of agricultural management and to investigate the impacts of plantation forestry management on stream water quality (Neal, 2000). All of these endeavours have produced a large volume of research and contract based publications (Neal, 1997b; Kirby et al., 1997).

Here, a summary is provided of the findings from the twenty years of research into the water quality functioning of the headwaters of the River Severn, from the perspective of research at CEH Wallingford and there are three main reasons for doing so. Firstly, it addresses the hydrochemical 
impacts of forestry harvesting on stream water quality. Other scientific studies dealing with in-catchment processes are dealt with in specialist publications from CEH Bangor (see citations above and Kirby et al. (1997) for a fuller compendium up to that year). Forestry research has been extensive at Plynlimon for both the CEH Bangor and Wallingford groups and much of this work was published by Neal and Reynolds (1999) who presented integrated findings up to that time. This forestry aspect coincides with the theme of this special issue of Hydrology and Earth Systems Science and it provides 'closure' for the CEH Wallingford research on the felling at Plynlimon. Secondly, the work indicates where the environmental research in this area, from both national and international perspectives, needs to proceed in terms of needs and gaps in knowledge, from the vantage point of the Plynlimon hydrochemistry science. Thirdly, it provides the reader with a selected bibliography of papers produced on the subject at $\mathrm{CEH}$ Wallingford, with references to companion studies. The new presentation makes up for any inadequacies in previous summaries (Neal, 1997b; Neal and Reynolds, 1999) now that considerably more information has been collected and extended monitoring has picked up new and important features. It is also a compilation of work disseminated across many papers in research journals as well as in contract reports.

\section{Background}

The Plynlimon study in the upper River Severn relates to two main tributaries, the Afon Hafren and the Afon Hore, and to a smaller sub-catchment, the Nant Tanllwyth, that enters the Afon Hafren near its junction with the Afon Hore (respective areas, $3.58,3.17$ and $0.916 \mathrm{~km}^{2}$ ). The upper parts of the Hafren and the Hore comprise hill top plateau dominated by blanket peat up to two metres deep whilst areas of seasonally saturated peat and gley soils occur in the valley bottoms. In the lower parts of the two catchments are first generation conifer plantations (mainly Sitka with some Norway spruce, Lodgepole pine and Larch). These plantations contrast with 'natural' conifer forests in that (a) the trees were closely spaced together and (b) the trees were planted in rows, where the soils in the rows had been furrowed to give sufficient depth for planting. Further, these furrowed rows were positioned in an uphill-downhill direction to allow free drainage: this induced 'very flashy' hydrograph responses to rainfall and enhanced rates of sediment transport (Newson, 1976; Newson and Leeks, 1987; Kirby et al., 1991; Leeks and Marks, 1997; Marks and Rutt, 1997). For these lower parts of the Hafren and Hore, the soils are of podzolic and gley types. These soils are acidic and they are typically less than $1 \mathrm{~m}$ thick. All of the Tanllwyth catchment is in the Hafren forest. The underlying bedrock across the Hafren, Hore and Tanllwyth catchments is 'hard-rock' Ordovician to Silurian age mudstones, grits and shales. The lower Hore was clear-felled during 1985-89 (Neal et al., 1992a,b) and a small tributary of the Hore, south2Hore was also monitored (Neal et al., 1994a, 2003c). The Hafren underwent phased felling over the last 20 or more years: now about two thirds of the forest has been felled (Neal et al., 2004a). For the Tanllwyth, the southern half of the catchment was felled in 1996 (Neal et al., 2004b). For the lower Hore and the Tanllwyth, clear felling was undertaken as an 'experimental fell' as part of joint research with the Forestry Commission and Forest Enterprise, to determine the maximum effects on water quality: in general, as with the Hafren, phased felling is standard practice and felling effects might be less pronounced due to 'dilution' of the response. Comparative studies for brown-earth soils at Vyrnwy are discussed by Neal et al. (2004c).

Monitoring of rainfall and stream water quality began in May 1983 on a weekly basis and the underlying approach was to study a wide range of chemical constituents to assess both the hydrological flow pathways at the catchment level and the impacts of conifer harvesting and replanting (Neal et al., 1997a). The underlying rationale at the inception of the monitoring programme was for the catchment to be treated as a 'black box' with measurements of rainfall 'input' and stream 'output', rather than for within catchment functioning. For the streams, initially only the lower Hafren and the lower Hore were monitored, the Hafren providing, supposedly, a control for the Hore clear fell. However, early results showed contrasting chemistry (the Hore had a higher weathering rate as shown by higher calcium, $\mathrm{pH}$ and Gran alkalinity levels (Neal et al., 1986; Reynolds et al., 1986). So, in 1984, the upper Hore was also monitored to provide a better control for the lower Hore (one of the main inputs of high Gran alkalinity waters was from a historic lead-zinc mine upstream of the upper sampling point on the Hore). All of these sites were situated near flow gauging flumes (Hudson et al., 1997b) in order that accurate comparison could be made between water quality change and hydrology. However, as the research progressed, the monitoring network was extended on a number of fronts (Neal and Kirchner, 2000):

- Stemflow and throughfall were measured at a site near the (then) Plynlimon field station (the Dollyd Office). This was undertaken to characterise the cycling of chemicals through the vegetation.

- Drainage from a small stream (south2Hore) was 
monitored pre-, during and post-felling from 1988 to provide information on runoff changes for forest and harvested forest within a small catchment dominated by near surface inputs to characterise a 'soil' as opposed to a 'groundwater' endmember (Neal et al., 2003c).

- Continuous monitoring of $\mathrm{pH}$ and conductivity was undertaken for rainfall and stream flow in the lower Hafren and the Tanllwyth from 1989 to 1993 to examine the dynamics of water quality response to change in hydrology (Robson et al., 1992a,b).

- Cloud-water was collected from 1990 when it became apparent from the research of others that 'occult' and dry deposition could provide important input fluxes for several major and trace elements (Wilkinson et al., 1997).

- The upper Hafren was monitored from 1990 to provide information on the chemistry of runoff from the moorland area (Neal, 2000).

- The Tanllwyth was monitored from 1991 to (a) provide data for a completely forested catchment and (b) provide baseline information for an experimental fell which took place in February 1996 (Neal et al., 2004b).

- Small (less than 5ha area) control and fell response sites were established in 1994 for podzolic and gley soils (the south-east sites of the Hafren and the Tan north and Tan south sites of the Tanllwyth, respectively). This work was undertaken as part of contracted research to examine the impacts of felling on water quality for the Environment Agency in conjunction with Forestry Commission and Forest Enterprise (Neal and Reynolds, 1999a,b).

- Groundwater samples were collected across a network of sites from 1994 when it became clear from the stream water quality data that the stream water could not simply be related to 'soil water' inputs as previously believed (Neal et al., 1997b,c). Rather the waters under baseflow conditions seemed to come from shallow groundwater areas which the borehole network confirmed.

Rainfall, cloud-water, and stream flow in the upper and lower Hafren, the upper and lower Hore and the Tanllwyth are still monitored, with monitoring of the other sites being stopped either when the information they were collecting was of diminishing importance, or when finance rather than science became dominant.

\section{Research findings}

Gaining an understanding of the water quality functioning of the Plynlimon catchments has taken the full length of the 20 -year study period and still the work is incomplete.
However, there are several aspects to understanding the hydrogeochemical functioning of the upper Severn catchments.

\section{WATER QUALITY CHANGES FROM THE WEEKLY TO THE DECADAL SCALE FOR UNDISTURBED FORESTED CATCHMENTS}

Starting from the viewpoint of the catchment being considered as a black box input-output relationship, the following can be said, based on weekly measurements.

- Despite being over $50 \mathrm{~km}$ from the sea or industrial sources, rainfall is not 'pure' (Neal et al., 1997a; Wilkinson et al., 1997). Rather, it has a variable chemistry which comprises three rudiments. Firstly, it contains salts originating in the North Atlantic and entering the atmosphere as sea-spray. This means that the rainfall can be enriched in components such as sodium, chloride, calcium, magnesium and sulphate. Secondly, it contains pollutant components such as transition metals, nitrate, ammonium, non-marine sulphur and dissolved organic carbon. The amounts of the sea-salts and pollutant components vary according to specific sources and air mass trajectories and concentrations can be very variable. Thirdly, there can be very large variability in chemistry even during individual events (Robson et al., 1992b).

- The rainfall concentration varies not only on an eventto-event basis but also on an annual or longer time step. This is shown by time series analysis where curvilinear or cyclic behaviour can occur on up to 10 yearly timescales (Robson and Neal, 1996; Neal et al., 2001). This, for example, is shown for zinc which has higher concentrations at the start and end of the 20 years record, and for chromium which peaked, probably in hexavalent form, during the mid-1980s (Neal et al., 1996). Often the pollutant inputs are highest under low volumes of rainfall catch and this links to a 'washout' mechanism where there is a limited supply of pollutant in the atmosphere which is diluted as rainfall volume increases.

- Cloud-water can provide a highly significant input to the total wet deposition with values, typically of the order of $40 \%$ for the sea-salt and pollutant components such as non-marine sulphate, nitrate, ammonium and several of the trace elements for the forested areas and about a half of this value for moorland areas (Wilkinson et al., 1997). The cloud-water is more concentrated than the rainfall, typically by an order of magnitude or more, for many elements although the annual volumetric input 
of cloud-water is relatively small at around $140 \mathrm{~mm}$ for forest and $33 \mathrm{~mm}$ for moorland, compared with annual average rainfall of $2459 \mathrm{~mm}$. As with rainfall, the highest concentrations link to the lowest volumes of catch and there are clearly changes occurring on the decadal scale with higher concentrations, particularly at low volumes of catch, of ammonium, nitrate and nonmarine sulphate during the mid-1990s (Neal et al., 2001).

- Within the streams, the rainfall signal is damped for components such as sodium and chloride which are of relatively low reactivity (when measured at the weekly scale appropriate at this part of the discussion qualification of this statement will come later when dealing with fine timescale resolution). However, strong variations in the water quality of the streams can be linked to the inputs of water from two distinct hydrochemical provenances. Firstly, under baseflow conditions the streams are of calcium and magnesium bicarbonate type, characteristic of waters that have reacted with the minerals in the bedrock (weathering processes). Secondly, under high flows the waters are acidic and aluminium-bearing and of low bicarbonate content. This reflects inputs from the acidic soils in the area, the aluminium being supplied from aluminium oxides/hydroxides in the soil that are leached under acidic conditions. At intermediate flows, the chemical concentrations change between these two endmember compositions according to the relative proportions of the soil and groundwater inputs.

- Nutrient components such as nitrate, bromine and iodine show annual cyclical patterns and this reflects changes in decomposition rates in the soil and uptake by the vegetation during the year (Neal et al., 1997a).

As with the rainfall and cloud-water, there are longer term patterns of water quality change within the rivers. The patterns take a number of forms.

- Chromium peaked in the streams during the mid-1980s (Neal et al., 1996) while zinc was highest during the early and late part of the record (Robson and Neal, 1996, Neal et al., 1997a). The reason for this increase is not clear other than it represents a pollutant source.

- Beryllium showed unusually high values for a short period late in November 1995 (Neal et al., 2003a) and similar patterns were observed in some lowland rivers about this time (Neal et al., 2003b). The reason for this peak is not clear, but rainfall was enhanced in beryllium around the same time as the streams and the peaks occurred after an extended drought period.
- Dissolved organic carbon also increased with time particularly over the first ten years of record, 1983-93 (Neal et al., 1997a). This seems to be a general feature of upland organic rich environments (Monteith and Evans, 2000; Worrall et al., 2004a,b). It is often associated with long-term increases in temperature in the uplands; these cause increased decomposition of peat and an increasing depth of oxidation as evaporation increases the depth to the water table. However, temperature cannot alone explain the increases in DOC production and uncertainty remains over the precise mechanisms operative (Worrall et al., 2004b). Iron shows a similar pattern of behaviour to DOC and this is probably linked to the iron being bound to organics in the water (Neal et al., 2001).

- Nitrate shows year to year variations. The highest concentrations of nitrate occurred during the earlier part of the record (1983-1986) and around 1996. However, there are no clear systematic trends to the data and the peak concentrations were observed across moorland, forested and previously felled sites in the Plynlimon area (Neal et al., 2001, 2002b,c). This pattern of change is not confined to the Plynlimon area, but includes surface acidification monitoring sites across the UK and it seems that the national changes are associated with climatic variations associated with factors such as the changeability in the North Atlantic Oscillation (Monteith et al., 2000): spring peaks seem to follow colder low North Atlantic Oscillation winters.

- Sodium and chloride show year to year variations and these seems to be driven by the fluctuation of the North Atlantic Oscillation, which strongly influences winter precipitation, its water quality and temperature patterns in regions bordering the North Atlantic (Evans et al., 2001).

\section{THE INTERNAL FUNCTIONING OF THE} CATCHMENTS

From the viewpoint of input-output budgets, the internal functioning of catchments is of second order importance, at least in the shorter term (year to year), while for process understanding it is a central issue.

Starting within the early to mid-1980s, modelling frameworks were developed which are still fundamental to the conceptualisation of catchments. These models, specifically designed for acidic and acid sensitive systems were based on simple process-based understanding (Neal, 1997b; Neal et al., 1997e). This understanding allowed for the key chemical reactions, such as cation and anion exchange and weathering processes which took place in the 
catchment, to be linked to atmospheric deposition of chemicals and hydrological interactions between the atmosphere, the soil and the stream (Cosby et al., 1985a,b, Christophersen et al., 1982, 1984). Such models comprised some of the greatest research outputs of the last 30 years and their influence on current thinking and developing research has been remarkable. For Plynlimon, the CEH Wallingford research, within a 'black box' setting, examined whether the underlying rationale for the models held true in the field and if field measurements could be used to define rigorously the process-based equations used in the models. Such an assessment was not confined to the Plynlimon studies and was indeed pioneered by one of the world's leading hydrological modellers, Nils Christophersen (Christophersen and Neal, 1990).

In agreement with the conceptualisation at that time, the dynamics of water quality change were 'simple' and were related directly to hydrology and water source areas. Acidic and aluminium bearing stream waters, depleted in calcium, occurred under stormflow conditions and these were essentially derived from the acidic soil zones. Correspondingly, calcium enriched circumneutral waters of low aluminium content occurred under baseflow conditions and these were representative of drainage from shallow groundwater areas where 'weathering reactions' neutralised inputs from the acidic aluminium bearing soil waters. This led to the development of methodologies for chemical splitting of the hydrograph (Christophersen et al., 1990; Neal et al., 1990a,b; Robson and Neal, 1990) and the development of 'end-member mixing analysis', EMMA (Hooper et al., 1990). However, for the type of 'hard rock' catchment system having thin soils that were important for Plynlimon and many other acidic and acid-sensitive areas of the world, a significant volume of groundwater was rarely suggested by the hydrological fraternity even though chemical hydrograph splitting across the flow range implied that it was (Neal et al., 1990a). None of this behaviour was inconsistent with the modelling work until consideration was given to the dampening of the high variability of components of low chemical reactivity (chloride and the stable water isotopes) when critical issues of modelling arose (Christophersen and Neal, 1990; Christophersen et al., 1993). This aspect will be dealt with later in the paper, but here the relevant part is that such damping implied a high volumetric groundwater storage (Neal et al., 1988).

As a consequence of the 'black box' approach indicating that groundwater was important, a series of exploratory boreholes was drilled in the Hafren catchment and groundwater was indeed found (Neal et al., 1997b,c). The results showed that the hydrogeological setting for the groundwater was that of fracture-flow. It was also found that the groundwater chemistry was very variable, with a chemistry varying between that observed for the streams under baseflow and stormflow, but extending to high alkalinities representative of high weathering rates. This was not expected and it did not fit well with either the modelling or hydrograph splitting concepts of a 'homogeneous groundwater end-member'. Indeed, the variations in chemistry implied that the groundwater fractures were acting as a conduit for the transport of soil waters under wet conditions and that the weathering reactions were nonuniform.

At that timer, issues of reactions within the soil were dealt with, from a black box approach, by looking at the dynamics of water quality change for tributaries and small seepages in the Plynlimon catchments. Here, the idea was that by looking at small areas of runoff, particularly those with ephemeral drainage, the soil water end-member could be examined and linked to the key process of cation exchange in the soil. The intention was to provide a mathematical representation of the cation exchange process for use in the modelling work. This effort failed in two important ways. Firstly, the expected power relationships between cations of differing charge for cation exchange were not observed (Neal et al., 1994a; Avila et al., 1995; Neal, 1996). Secondly, there was no uniformity in the runoff chemistry for these sub-catchments other than dynamic changes in water quality with flow reflecting those observed between water quality and flow observed in the stream (Hill and Neal, 1997; Neal et al., 1997d). The variation in chemistry across the sites was not predictable from factors such as slope and there were no clear differences in the underlying bedrock and even for ephemeral streams, shallow groundwater could be an important component of flow. This high degree of heterogeneity was also mirrored within regional survey and detailed process studies both at Plynlimon and elsewhere (Neal, 1997b; Neal et al., 1998b). For example, multiple soil water samplers were required to integrate an observed high degree of soil water chemistry variability, and where the cation exchange fraction of the soil had large variability in chemistry (Reynolds et al., 1988; Mulder et al., 1991; Taugbøl and Neal, 1993). Indeed, detailed cation exchange studies on the Plynlimon soils indicated an extremely complex and dynamic process involving inorganic, organic and biological interactions that cannot be separated easily or pinned down mathematically in a process-based sense (Neal et al., 1990c). Thus, at a detailed level, the field measurements implied that there was uncertainty over what cation exchange formulae could be used in the models and that the soil water system was highly heterogeneous: both features did not fit well with the classic modelling framework (Neal, 2002a). Yet, despite this, there were 
cryptic clues over the mechanisms occurring within the catchments as linked to cation exchange reactions. These clues took three forms. Firstly, for highly heterogeneous systems, linear relationships could occur for cations of differing charge due to cation exchange reactions and the nature of the mixing reactions (Neal, 1992). Secondly, there was a linear relationship between sodium and chloride in both rainfall and stream waters, but the gradient of the line was consistently different between the two water types (Neal and Kirchner, 2000). Both sodium and chloride within the streams come from the atmosphere: chloride can be considered inert within the catchment while sodium takes part in only cation exchange reactions: there is no significant weathering source for either sodium or chloride. Sodium is damped more than chloride in the streams relative to rainfall: i.e. the gradient $\mathrm{dNa} / \mathrm{dCl}$ is lower in the stream relative to rainfall. This pattern is what would be predicted with cation exchange, where at low sodium and low chloride concentrations, sodium would be released from the cation exchange sites to the soil solution while at high concentrations of sodium and chloride, sodium would be sorbed to a higher degree due to classic cation exchange theory (Neal and Kirchner, 2000). In other words, while the catchment storage ensured a dampening of the rainfall sodium and chloride input, the cation exchange process damped out the sodium input signal from rainfall even further. Thirdly, when considering flux transfers rather than differences in concentration, the relative changes for the major cations follow that anticipated with cation exchange. Thus, the flux term integrates the heterogeneity experienced within the catchment in relation to concentration and cation exchange controls in a way which is clearly discernable in a mechanistic sense (Neal, 2002b).

In terms of process, atmospheric inputs need comment. Generally. it is considered that rainfall provides a good measure of the input of chemicals to the catchment. This is not necessarily the case. Mist and dry deposition can provide additional significant inputs (Wilkinson et al., 1997), and yet these are not measured routinely or, where they are collected, there is difficulty in estimating flux as opposed to the measure of 'catch' (i.e. a concentration). Further, the amount of catch varies with altitude, wind speed, vegetation cover etc, and this adds to the difficulty of providing a good estimate of deposition flux. For example, very high deposition of chloride can occur within localised areas of the catchment (Neal et al., 2003c). Further, there can be a high degree of chemical variability in throughfall and stemflow linked to complex cycling of chemicals through the vegetation and/or non-uniform deposition of chemicals onto the vegetation (Neal et al., 1994b; Robson et al., 1994). Currently in catchment input-output water quality flux studies, it is standard to correct for cloud and dry deposition for particular determinands by assuming a net input-output balance for chloride to assess the uptake/release of chemicals to/from the catchment. There are major question marks over the value of this. The uncertainty over the inputs is important both in terms of assessing input-output balances, long term changes in catchment stores, flux transfers, storage and heterogeneity.

Thus, while current concepts of how catchments function in terms of hydrology and hydrogeochemistry are accepted within a broad sense, in detail, the catchments are highly heterogeneous with regard to inputs, biogeochemical cycling and within catchment processing. This makes pinning down the fundamental processes difficult, both from the stance of field measurements and modelling.

\section{SHORT TERM DYNAMICS OF WATER QUALITY CHANGE}

The variation in water quality for the Plynlimon streams relates in many instances to changes in hydrology, which operate on the sub-daily scale. Hence, to measure the dynamics of the Plynlimon streams, as elsewhere, there has been the need to monitor through events (Hill and Neal, 1997; Foster et al., 1997, 2001). However, one of the most surprising aspects of how the water quality changes over short time intervals in the Plynlimon streams came about with an examination of the long-term weekly rainfall and runoff record for chloride, augmented with over three years of daily data at Plynlimon. The data examined was for rainfall, and for the lower Hafren and Tanllwyth stream (Kirchner et al., 2000; Neal and Kirchner, 2000). As commented upon above, chloride is expected to have low chemical reactivity and hence should not show the degree of damping in the stream that is observed without apparently a large groundwater reservoir, which is not the case. However, as shown by Kirchner et al. (2000, 2001), there is a pattern to the chloride variations in the Plynlimon streams corresponding to a ' $1 / \mathrm{f}$ ' fractal structure even though the rainfall input shows only 'white noise'. This pattern does not link directly to flow as do components such as acidity, calcium and aluminium. Hence, detailed monitoring based on specific events is not sufficient to show the variability in the spectrum of responses to different chemicals within the streams. Rather, there is a need for monitoring on both a regular and a flow response driven basis. The fractal patterns can be linked to the internal functioning of catchments in a deterministic way but there may well be several models which can describe the changes taking place (Kirchner et $a l, 2001)$. Here, a fractal is taken as comprising: "A repetition of pattern or process across many scales to give an end 
product which does not fit within ideal (Platonic) dimensions." Previous detailed monitoring and dynamic modelling studies have focused on the changes in determinands linked directly to the issues of acidification $(\mathrm{pH}$, alkalinity, ANC, divalent base cations, sulphate and aluminium) and which show more 'regular behaviour' in response to changing hydrology. Further, event monitoring is time consuming and often 'hit or miss' due to the irregularity of rainfall events. In consequence, daily or subdaily data over an extended period are not available. However, some short term data based on the use of continuous monitors are available. During the early to mid1990s Alice Robson examined the short-term responses in the Hafren streams in relation to $\mathrm{pH}$ and conductivity (Robson, 1993; Robson and Neal, 1991; Robson et al., 1992a,b, 1993, 1995). The conductivity signal reflects to a large degree the atmospheric input of sea-salt components such as chloride but there are some influences from $\mathrm{pH}$ (hydrogen ions have a higher specific ion conductivity) and high alkalinity waters under baseflow conditions (the conductivity of calcium, magnesium and bicarbonate become more important). Robson and co-workers clearly showed complex but substantial patterns of change in conductivity at sub-daily intervals that link only in part to the variations in input flux from the rainfall that generated the event monitored in the stream, or the previous rainfall event. Robson (1993), in her doctoral studies indicated that as the timing interval between sampling was increased, there was a clear loss in the information content of the signal (i.e. the dynamic characteristics were reduced or lost). The true significance of this finding is now becoming much clearer within the context of catchment studies linked to fractal processes as the complexity of the response is in line with the predictions of Kirchner et al. (2001) who theorised that the water quality could change markedly at fine time resolutions owing to localised inputs within the highly heterogeneous catchment system. Indeed, having such data provides a rigorous test for conceptual understanding of how the catchments and the various catchment stores actually function, in a way that field measurements cannot do. For example, monitoring at finer and finer resolutions leads to increased complexity with no way of scaling back to the catchment level and no way of defining mathematically the key processes involved. This feature was summarised emotively by Kirchner et al. (2004) who made a plea for finer resolution data over long time periods. By making do with weekly or monthly water quality sampling, only the most persistent features are seen. Significantly, Kirchner $e t$ al. (2004) make an analogy with music. Imagine trying to listen to a symphony if one hears a note only every minute or two. That is analogous to trying to infer the hydrochemical functioning of a catchment from weekly or monthly grab samples. Correspondingly, imagine trying to understand a symphony from a few crashing chords. That is what happens when one tries to analyse intensive samples for the occasional storm event. To understand the symphony of catchment hydrochemical behaviour, all the notes need to be heard.

With regard to the complexity of the response, part of this complexity may well relate to the fracture size and distribution within the bedrock and to the variable pore size distribution within the soil that attenuates the chemical signal and leads to a complex distribution of water and chemical residence times. As noted earlier, the chloride rainfall signal is highly damped in the stream, although there are some clear responses in the streams to years with particularly high chloride inputs in rainfall. Yet, for chromium clearly distributed in rainfall, there is broadly a matched signal within the stream. Longer term patterns of rainfall signal are reflected in the stream. However, it may also be linked to the degree to which the different components can be retained by the catchment in relation to the pore/fracture sizes that particular determinands can penetrate. Chromium, in the form of chromate or dichromate is a larger ion than chloride and there may well be a size related effect which means that the bigger ion can move faster through the catchment than smaller ions. If this is true, then there are major issues of pollutant and pathogen transport to be addressed in the future.

Thus, there is a considerable variation in stream water chemistry that is now being revealed with fine resolution monitoring. Much of this work goes against conventional thinking where the catchment outlet is supposed to integrate the catchment response for water quality in a way that there is 'little information content' in the dynamic pattern of change at the catchment outlet. It also goes against conventional views that the catchment is or can be simplified, for modelling or conceptual purposes, to that of homogeneous units that can be described by processes calibrated either in the test tube or the local catchment scale. There is much to this, and further comments will be made in the conclusions section, but a pointer is given by the title of the Kirchner et al. (2004) paper: "The fine structure of water-quality dynamics: the (high-frequency) wave of the future."

\section{FOREST HARVESTING IMPACTS ON WATER QUALITY}

The major response to felling, for many studies, is one of an increase in nitrate with possible increases in dissolved organic carbon (DOC), $\mathrm{K}, \mathrm{Al}$ and acidity (i.e. lower $\mathrm{pH}$ and 
lower Gran alkalinity) with decreases in 'sea-salt' components such as sodium and chloride, which derive from atmospheric sources, due to reduced evaporation (greater runoff increasing dilution) and reduced scavenging of mist and particles from the atmosphere by the vegetation (Neal et al.. 1992a,b, 1998a,b; Neal and Reynolds, 1999). These changes then recede after a few years as nitrate uptake by the vegetation increases and the concentration of acid anions decreases. Indeed, this can even lead to better water quality than before the trees were felled (Neal, 2003b,c). Despite this, the changes are not uniform and there are several features of the physical nature of the catchments and the management practices which complicate the issue. Specifically,

- The largest changes occur with clear felling: phased felling results in a "dilution of the impacts" (Neal et al., 1992a,b, 1994a, 2004a,b).

- There are marked variations in the water quality response to felling at the local scale (Neal et al., 1998a,b; Neal and Reynolds, 1999a,b,c,d). This is characteristic of the highly heterogeneous system being examined.

- With felling, the catchment draining gley show marked and relatively short-lived peaks in ammonium and phosphate at the local scale. This reflects the soil/ biogeochemical disturbance and the reducing conditions within the soil (Neal et al., 2004b).

- There are barely any changes in water quality associated with felling for the gley soils at the catchment scale: there is even an absence of a clear nitrate pulse associated with felling. It seems that a system which would be expected to show the biggest impact (very acidic soils with high surface runoff during hydrological events), actually shows the least response at the catchment scale. For the upland areas, the waters are nutrient limiting with respect to phosphorus and it seems that the release in phosphorus has stimulated biological activity within the streams, thus removing the water quality products of the felling (Neal et al., 2002c, 2004b).

- Where there is phased felling over many years, the water quality response is hardly noticeable (Neal et al., 2004a).

- The water quality changes are often within the noise of the longer term changes associated with other factors such as climate change and climate variability (Neal and Reynolds, 1999).

\section{Conclusions}

It is now 20 years since the inception of the CEH Wallingford led research into the water quality functioning of the upper River Severn. From a starting point of a 'black box' approach to input-output relationships, key features of the hydrogeochemical functioning have been identified as linked to process understanding and clear felling. One of the key findings is that the water quality variation in the streams and in rainfall has changed over time in relation to hydrology and climate, as well as, in the case of the streams, due to forestry practice. When the CEH Wallingford hydrochemical programme started it was not envisaged that the research would last for 20 years, but clearly the longterm patterns of change imply a need to continue the monitoring in relation to issues such as pollution climate, climate change and climate instability, and forestry rotation cycles for many years to come. Early on in the programme, and perhaps up to five or ten years ago, it was thought that by examining the catchment in detail the underlying mechanisms of water quality functioning and withincatchment processes could be assessed and used to predict water quality change in a deterministic way. Starting from the 'black box' approach and gradually examining catchment responses at the local scale and within-catchment processes in more and more detail, this deterministic route has proved hard to justify. Rather, by looking more and more into the spatial variability (from the $\mathrm{km}$ to the $\mu \mathrm{m}$ scale) the system has been found to be more complex and harder to explain; there are also fundamental issues of how to scale up information from the local to the catchment level in a scientifically rigorous and numeric way. There has been, and to a large extent there still remains, a common view that the water quality changes observed at the catchment outlet are simple and contain little 'information content'. However, continuous monitoring of conductivity in the early 1990s showed much more complexity at a time scale of minutes rather than weeks and daily measurements of chloride in the stream when linked to long-term weekly measurements revealed a fractal structure. This detail is now being incorporated in theoretical and practical modelling developments based on the recognition of the highly heterogeneous nature of the catchments. Thus, by combining minute with daily and weekly data over the decadal and longer timescales, within newly developing modelling approaches, the nature of the internal functioning of catchments may be explored in a way with which detailed process studies cannot compete. This is a clear case where the 'measuring' and 'modelling' fraternities need to work closely together. While fractal behaviour can now be described in mechanistic modelling frameworks, no unique model can automatically be chosen as representative. Rather, probably many models can describe the changes taking place and there is no clear way of making field measurements in catchments to resolve the differences although longer term monitoring might clarify matters further. The long term time 
series cannot identify the underlying mechanisms within the catchment, but the detailed time series may be able to eliminate some of the modelling frameworks which other approaches cannot. This means that while focus can be on options for modelling and conceptualising how catchments function, there remains 'a knowledge gap' or 'structural uncertainty gap' of how catchments behave with respect to water quality. Today's science cannot as yet bridge this gap. As such, the need for long and detailed measurements to be continued and expanded becomes clear. This is demanded in terms of the variability of the input signals, the complexity of within-catchment processes and the variability and irregularity of stream water quality over time. It is also demanded because stream water issues are not confined simply to what is generally considered to be important by funding agencies, and because of the lack of achievability of definitive process-based models to describe environmental change. A firm theoretical and philosophical basis is essential: 'physics-based' approaches are to be commended, as is the comment of Kirchner et al. (2004) on "the fine structure of water-quality dynamics: the (highfrequency) wave of the future" has a structural significance both in terms of 'waveforms' and 'discrete quantized packages.'

With regard to forestry issues and water quality functioning, felling sometimes results in a deterioration in water quality. Nonetheless, this deterioration is often small and short-lived (one or two years) and can be minimised by phased felling, which is now standard forestry practice in the UK. Further, the recovery phase may well be one of improved water quality. For example, in the case of nitrate, concentrations are higher for one or two years post-felling, but then can decline to levels lower than before felling. Indeed, it is not clear that throughout the forest cycle there will be net output flux of nitrate. Rather, a net balance might well be anticipated as nitrogen is incorporated into the growing biomass and the soil store. Similar arguments can be made over issues such as acidification where the initial phase of felling which releases nitrate can acidify the waters, while progressive reductions in 'sea-salt' components following felling will result in a lowering of acidity. Thus, after the nitrate felling surge is over, the stream water acidity can be lower than before felling commenced. However, there remain issues of sustainability as there are question marks over the extent to which the developing second generation of forest takes in calcium and magnesium from cation exchange sites or the bedrock. If calcium and magnesium uptake from the soil is important then soil acidification may occur, while if it is taken from bedrock sources then it will not lead to soil acidification and may even reverse it. Overall, set within the context of the complexity of catchment responses and the changing influences of climate variability and climate change, felling effects on water quality seem to be of second-order importance.

\section{References}

Avila, A., Bonilla, D., Roda, F., Pinol, J. and Neal, C., 1995. Soil water chemistry in a Holm oak (Quercus ilex) forest: inferences on biogeochemical processes for a montane-Mediterranean area. J. Hydrol., 166, 15-35.

Christophersen, N. and Neal, C., 1990. Linking hydrological, geochemical, and soil chemical processes on the catchment scale: an interplay between modelling and field work. Water Resour. Res., 26, 3077-3086.

Christophersen, N., Seip, H.M. and Wright, R.F., 1982. A model for stream water chemistry at Birkenes, Norway. Water Resour. Res., 18, 977-996.

Christophersen, N., Rustad, S. and Seip, H.M., 1984. Modelling streamwater chemistry with snowmelt. Phil. Trans. Roy. Soc., London, UK, B, 305, 427-439.

Christophersen, N., Neal, C., Hooper, R.P., Vogt, R.D. and Andersen, S., 1990. Modelling streamwater chemistry as a mixture of soilwater end-members - a step towards second generation acidification models. J. Hydrol., 116, 307-320.

Christophersen, N., Neal, C. and Hooper, R.P., 1993. Modelling the Hydrochemistry of catchments: a challenge for the scientific method. J. Hydrol., 152, 1-12.

Cosby, B.J., Wright, R.F., Hornberger, G.M. and Galloway, J.N., 1985a. Modelling the effects of acidic deposition: assessment of a lumped-parameter model of soil water and stream water chemistry. Water Resour. Res., 21, 51-63.

Cosby, B.J., Wright, R.F., Hornberger, G.M. and Galloway, J.N., 1985b. Modelling the effects of acid deposition: estimation of long-term water quality responses in a small forested catchment. Water Resour. Res., 21, 1591-1601.

Evans, C. D., Monteith, D.T. and Harriman, R., 2001. Long-term variability in the deposition of marine ions at west coast sites in the UK Acid Waters Monitoring Network: impacts on surface water chemistry and significance for trend determination. Sci. Total Environ., 265, 115-129.

Foster, H., Alexander, S., Locks, T. Wheater, H., Lees, M.J. and Reynolds, B., 1997. Scale dependence of the episodic hydrochemical response of nested catchments at Plynlimon. Hydrol. Earth Syst. Sci., 1, 639-651.

Foster, H., Lees, M.J., Wheater, H., Neal, C. and Reynolds, B., 2001 A hydrochemical modelling framework for combined assessment of spatial and temporal variability in stream chemistry: application to Plynlimon, mid-Wales. Hydrol. Earth Syst. Sci., 5, 49-58.

Hill, T. and Neal, C., 1997. Spatial and temporal variation in $\mathrm{pH}$, alkalinity and conductivity in surface runoff and groundwater for the Upper River Severn catchment. Hydrol. Earth Syst. Sci., $1,697-716$.

Hooper, R.P., Christophersen, N. and Peters, N.E., 1990. Modelling streamwater chemistry as a mixture of soilwater endmembers an application to the Panola Mountain catchment, Georgia, USA. J. Hydrol., 116, 321-343.

Hornung, M., Reynolds, B. and Hatton, A.A., 1985. Land management, geological and soil effects on stream water chemistry in upland mid-Wales. Appl. Geog., 5, 71-80.

Hornung, M., Adamson, J.K., Reynolds, B. and Stevens, P.A. 1986a. Influence of mineral weathering and catchment hydrology on drainage water chemistry in three upland sites in England and Wales. J. Geol. Soc. London, 143, 627-634. 
Hornung, M., Stevens, P.A. and Reynolds, B., 1986b. The impact of pasture improvement of the soil solutions chemistry of some stagnopodzols in mid-Wales. Soil Use Manage., 2, 18-26.

Hudson, J.A., Gilman, K. and Calder, I., 1997a. Land use and water quality issues in the uplands with reference to the Plynlimon study. Hydrol. Earth Syst. Sci., 1, 389-397.

Hudson, J.A., Crane, S.B. and Blackie, J.R., 1997b. The Plynlimon water balance 1969-1995: the impact of forest and moorland vegetation on evaporation and streamflow in upland catchments. Hydrol. Earth Syst. Sci., 1, 409-427.

Kirby, C., Newson, M.D. and Gilman, K., 1991.Plynlimon research: the first two decades. Inst. Hydrol. Report 109. Instute of Hydrology, UK, 188pp.

Kirby, C., Neal, C., Turner, H. and Moorhouse, P., 1997. A bibliography of hydrological, geomorphological, sedimentology, biological and hydrochemical references to the Institute of Hydrology experimental catchment studies in Plynlimon. Hydrol. Earth Syst. Sci., 1, 755-763.

Kirchner, J.W., Feng, X. and Neal, C., 2000. Fractal stream chemistry and its implications for contaminant transport in catchments. Nature, 403, 524-527.

Kirchner, J.W., Feng, X. and Neal, C., 2001. Catchment-scale advection and dispersion as a mechanism for fractal scaling in stream tracer concentrations. J. Hydrol. 254, 81-100.

Kirchner, J.W., Feng, X., Neal, C. and Robson, A.J., 2004. The fine structure of water-quality dynamics: the (high-frequency) wave of the future. Hydrol. Process, 18, 1353-1359.

Leeks, G.J.L. and Marks, S.D., 1997. Dynamics of river sediments in forested headwater streams. Hydrol. Earth Syst. Sci., 1, 483497.

Marks, S.D. and Rutt, G.P., 1997. Fluvial sediment inputs to upland river gravel beds draining forested catchments: potential ecological impacts. Hydrol. Earth Syst. Sci., 1, 499-509.

McCulloch, J.S.G., 1970. Catchment area research. Process Inst. Civ. Eng., Nov, 1-3.

McCulloch, J.S.G., 1997. Foreword: An historical view from the watershed. Hydrol. Earth Syst. Sci., 1, 381-384.

McCulloch, J.S.G. and Robinson, M., 1983. History of Forest Hydrology. J. Hydrol., 150, 189-216.

Monteith, D.T. and Evans, C.T., 2000. UK Acid Waters Monitoring Network: 10 year report. ENSIS Publishing, London, UK, and the report may be downloaded via the UKAWMN web page: http:/www.geog.ucl.ac.uk/awmn/. 364pp.

Monteith, D.T., Evans, C.D. and Reynolds, B., 2000. Are temporal variations in the nitrate content of UK upland freshwaters linked to the North Atlantic Oscillation? Hydrol. Process, 14, 17451749 .

Mulder, J., Pijpers, M. and Christophersen, N., 1991. Water flow pathways and the special distribution of soils and exchangeable cations in an acid rain impacted and a pristine catchment in Norway. Water Resour. Res., 27, 2919-2928.

Neal, C. 1992. Describing anthropogenic impacts on stream water quality: the problem of integrating soil water chemistry variability. Sci. Total Environ., 115, 207-218.

Neal, C. 1996. Towards lumped integrated models of complex heterogeneous systems. (Special Issue) Sci. Total Environ., 183, $115-124$

Neal, C., (Ed), 1997a. Water quality of the Plynlimon Catchment (UK). Hydrol. Earth System Sci., 1, 381-764.

Neal, C., 1997b. A view of water quality from the Plynlimon watershed. Hydrol. Earth System Sci., 1, 743-754.

Neal, C., 2000. Catchment science in a heterogeneous world: reflections on the water quality functioning of the Plynlimon catchments, Plynlimon, mid-Wales. In: Water in the Celtic Wold: managing resources for the 21 st century (J.A.A. Jones, K. Gilman, A. Jigorel, A. and J. Griffin, (Eds.) BHS Occasional
Paper, 11, 189-196.

Neal, C., 2002a. From determination to fractal processing, structural uncertainty and the need for continued long-term monitoring of the environment: the case of acidification. Hydrol. Process, 16, 2481-2484.

Neal, C., 2002b. Assessing environmental impacts on stream water quality: the use of cumulative flux and cumulative flux difference approaches to deforestation of the Hafren Forest, midWales. Hydrol. Earth Syst. Sci., 6, 421-432.

Neal, C. 2002c. Nutrient concentrations and fluxes for podzolic and gley soils at Plynlimon, mid-Wales: implications for modelling inorganic nitrogen and phosphorus in upland UK environments. Hydrol. Earth Syst. Sci., 6, 403-420.

Neal, C., 2003a. Dissolved beryllium in rainfall, stream and shallow groundwaters in the Upper River Severn catchments, Plynlimon, mid Wales. Sci. Total Eviron., 314-316, 171-184.

Neal, C., 2003b. Dissolved and acid available particulate beryllium in eastern UK surface waters. Sci. Total Eviron., 314-316, 185208.

Neal, C. and Reynolds, B., 1999a. The impact of conifer harvesting and replanting on upland water quality. $\mathrm{R} \& \mathrm{D}$ Technical report to the Environment Agency: Report P211, 137pp.

Neal, C. and Reynolds, B., 1999b. The impact of conifer harvesting and replanting on upland water quality. Project report to the Environment Agency: R\&D Project P2-067. 1. Main text, 121pp.

Neal, C. and Reynolds, B., 1999c. The impact of conifer harvesting and replanting on upland water quality. Project report to the Environment Agency: R\&D Project P2-067. 2. Figures, Tables and Appendices, 102pp.

Neal, C. and Reynolds, B., 1999d. The impact of conifer harvesting and replanting on upland water quality. Project report to the Environment Agency: R\&D Project P2-067. 3. A compendium of water quality time series, $84 \mathrm{pp}$.

Neal, C. and Kirchner, J.W., 2000. Sodium and chloride levels in rainfall, mist, streamwater and groundwater at the Plynlimon catchments, mid-Wales: inferences on hydrological and chemical controls. Hydrol. Earth Syst. Sci., 4, 295-310.

Neal, C., Smith, C.J., Walls, J. and Dunn, C.S., 1986. Major, minor and trace element mobility in the acidic upland forested catchment of the upper River Severn, Mid-Wales. J. Geol. Soc. London, 143, 635-648.

Neal, C., Christophersen, N., Neale, R., Smith, C.J., Whitehead, P.G. and Reynolds, B. 1988. Chloride in precipitation and streamwater for the upland catchment of the River Severn, MidWales; some consequences for hydrochemical models. Hydrol. Process, 2, 156-165.

Neal, C., Robson, A.J. and Smith, C.J., 1990a. Acid neutralization capacity variations for the Hafren forest stream, mid-Wales: inferences for hydrological processes. J. Hydrol., 121, 85-101.

Neal, C., Smith, C.J., Walls, J., Billingham, P., Hill, S. and Neal, M., 1990b. Hydrochemical variations in Hafren forest stream waters, Mid-Wales. J. Hydrol., 116, 185-200.

Neal, C., Mulder, J., Christophersen, N., Neal, M., Waters, D., Ferrier, R.C., Harriman, R. and McMahon, R., 1990c. Limitations to the understanding of ion-exchange and solubility controls for acidic Welsh, Scottish and Norwegian sites. $J$. Hydrol., 116, 11-23.

Neal, C., Fisher, R., Smith, C.J., Hill, S., Neal, M., Conway, T., Ryland, G.P. and Jeffery, H.A., 1992a. The effects of tree harvesting on stream water quality at an acidic and acid sensitive spruce forested area: Plynlimon, Mid-Wales. J. Hydrol., 135, 305-319.

Neal, C., Reynolds, B., Smith, C.J., Hill, S., Neal, M., Conway, T., Ryland, G.P., Jeffery, H.A. and Fisher, R., 1992b. The impact of conifer harvesting on stream water $\mathrm{pH}$, alkalinity and aluminium concentrations for the British uplands: an example 
for an acidic and acid sensitive catchment in Mid-Wales. Sci. Total Environ., 126, 75-87.

Neal, C., Neal, M., Ryland, G.P., Jeffery, H.A., Harrow, M., Hill, S. and Smith, C.J., 1994a. Chemical variations in near surface drainage water for an acidic spruce forested UK upland area subjected to timber harvesting: inferences on cation exchange processes in the soil. Sci. Total Environ., 154, 47-61.

Neal, C., Ryland, G.P., Conway, T., Jeffery, H.A., Neal, M., Robson, A.J., Smith, C.J., Walls, J. and Bhardwaj, C.L., 1994b. Interception of chemicals at a forest edge for a rural low-lying site at Black Wood, Hampshire, Southern England. Sci.. Total Environ., 142, 127-141.

Neal, C., Smith, C.J., Jeffery, H.A., Harrow, M.L. and Neal, M., 1996. Dissolved chromium pollution in rainfall and surface waters in Mid-Wales during the mid 1980s. Sci. Total Environ., 188, 127-138.

Neal, C., Wilkinson, R.J., Neal, M., Harrow, M.L., Wickham, H., Hill, L. and Morfitt, C., 1997a. The hydrochemistry of the River Severn, Plynlimon, Wales. Hydrol. Earth Syst. Sci., 1, 583-618.

Neal, C., Robson, A.J., Shand, P., Edmunds, W.M., Dixon, A.J., Buckley, D.K., Hill, S., Harrow, M.L., Neal, M. and Reynolds, B., 1997b. The occurrence of groundwater in the Lower Palaeozoic rocks of upland Central Wales. Hydrol. Earth Syst. Sci., 1, 3-18.

Neal, C., Hill, T., Alexander, S., Reynolds, B., Hill, S., Dixon, A.J., Harrow, M.L., Neal, M. and Smith, C.J., 1997c. Stream water quality in acid sensitive UK upland areas, an example of potential water quality remediation based on groundwater manipulation. Hydrol. Earth Syst. Sci., 1, 185-196.

Neal, C., Hill, T., Hill, S. and Reynolds, B., 1997d. Acid neutralization capacity measurements in surface and ground waters in the Upper River Severn, Plynlimon: from hydrograph splitting to water flow pathways. Hydrol. Earth Syst. Sci., 1, 687-696.

Neal, C., Robson, A.J. and Christophersen, N., 1997e. Towards coupling hydrological, soil and weathering processes within a modelling perspective. In: Geochemical Processes, Weathering and Groundwater Recharge in Catchments (ed. by O.M. Saether and P. de Caritat), Balkema, Rotterdam, The Netherlands. 329380.

Neal, C., Reynolds, B., Adamson, J.K., Stevens, P.A., Neal, M., Harrow, M., and Hill, S., 1998a. Analysis of the impacts of major anion variations on surface water acidity particularly with regard to conifer harvesting: case studies from Wales and Northern England. Hydrol. Earth Syst. Sci., 2, 303-322.

Neal, C., Reynolds, B., Wilkinson, J., Hill, T., Neal, M., Hill, S., and Harrow, M., 1998b. The impacts of conifer harvesting on runoff water quality: a regional study for Wales. Hydrol. Earth Syst. Sci., 2, 323-344.

Neal, C., Reynolds, B., Neal, M., Pugh, B., Hill, L. and Wickham, H., 2001. Long term changes in the water quality of rainfall, cloud-water and stream water for moorland, forested and clearfelled catchments at Plynlimon, mid-Wales. Hydrol. Earth Syst. Sci., 5, 459-476.

Neal, C., Reynolds, B., Neal, M., Hughes, S., Wickham, H., Hill, L., Rowland, P. and Pugh, B., 2003a. Soluble reactive phosphorus levels in rainfall, cloud water, throughfall, stemflow, soil waters, stream waters and groundwaters for the Upper River Severn area, Plynlimon, mid Wales. Sci. Total Environ., in press. Neal, C., Reynolds, B., Neal, M., Hill, L., Wickham, H., and Pugh, B., 2003b. Nitrogen in rainfall, cloud water, throughfall, stemflow, stream water and groundwater for the Plynlimon catchments of mid-Wales. Sci. Total Eviron., in press.

Neal, C., Reynolds, B., Neal, M., Wickham, H., Hill, L. and Pugh, B., 2003c. The Impact of Conifer Harvesting on Stream Water Quality: A Case Study in Mid-Wales. Water Air Soil Pollut. Focus, 3, 119-138.
Neal, C., Reynolds, B., Neal, M., Wickham, H., Hill, L. and Williams, B., 2004a. The impact of conifer harvesting on stream water quality: the Afon Hafren, mid-Wales. Hydrol. Earth Syst. Sci., 8, 503-520.

Neal, C., Reynolds, B., Neal, M., Wickham, H., Hill, L. and Williams, B., 2004b. The water quality of streams draining a plantation forest on gley soils: the Nant Tanllwyth, Plynlimon mid-Wales. Hydrol. Earth Syst. Sci., 8, 485-502.

Neal, C., Reynolds, B., Neal, M., Wickham, H., Hill, L. and Williams, B., 2004c. The hydrochemistry of plantation spruce forest catchments with brown earth soils, Vyrnwy in mid-Wales. Hydrol. Earth Syst. Sci., 8, 460-484.

Newson, M.D. 1976. The physiography, deposits and vegetation of the Plynlimon catchments. Institute of Hydrology Report no. 30, Wallingford, UK, 188pp.

Newson, M.D., 1985. Twenty years of catchment process studies: what have we taught the Engineers? In: Advances in water engineering, T.H.Y.Tebbutt, (Ed.), Elsevier, London. 39-46.

Newson, M.D. and Leeks, G.J.L., 1987. Transport processes at the catchment scale: a regional study of increasing sediment yield and its effects in mid-Wales. In: Sediment transport in gravel bed rivers C.R. Thorne, J.C. Bathurst, and R. Hey (Eds.) Wiley, Chichester, UK. 187-224.

Reynolds, B., 1983. The chemical composition of snow at a rural upland site in mid-Wales. Atmos. Environ., 17, 1849-1851.

Reynolds, B., 1984. An assessment of the spatial variation in the chemical composition of bulk precipitation within an upland catchment. Water Resour. Res., 20, 733-735.

Reynolds, B., Neal, C., Hornung, M and Stevens, P.A., 1986. Baseflow buffering of stream water acidity in five mid-Wales catchments. J. Hydrol., 87, 167-185.

Reynolds, B., Neal, C., Hornung, M., Hughes, S. and Stevens, P.A., 1988. Impact of afforestation on the soil solution chemistry of stagnopodzols in Mid-Wales. Water Air Soil Pollut., 38, 55-70.

Reynolds, B., Emmett, B.A. and Woods, C., 1992. Variations in streamwater nitrate concentrations and budgets over 10 years in a headwater catchment in mid-Wales. J. Hydrol., 136, 155175.

Reynolds, B., Renshaw, M., Sparks, T.H., Crane, S, Hughes, S., Brittain, S.A. and Kennedy, V.H., 1997a. Trends and seasonality in streamwater chemistry in two moorland catchments of the upper Wye, Plynlimon. Hydrol. Earth Syst. Sci., 1, 571-581.

Reynolds, B., Fowler, D., Smith, R.I. and Hall, J.R., 1997b. Atmospheric inputs and catchment solute fluxes for major ions in five Welsh upland catchments. J. Hydrol., 194, 305-329.

Robson, A.J., 1993. The use of continuous measurement in understanding and modelling the hydrochemistry of the uplands. $\mathrm{PhD}$ thesis, University of Lancaster, UK. 278pp.

Robson, A.J. and Neal, C., 1990. Hydrograph separation using chemical techniques: An application to catchments in MidWales. J. Hydrol., 116, 345-363.

Robson, A.J. and Neal, C., 1991. Chemical signals in an upland catchment in Mid-Wales - some implications for water movement. Third National Hydrology Symposium, British Hydrol. Soc., Univ. Southampton, UK, 16-18 September; 3.173.24 .

Robson, A.J. and Neal, C., 1996. Water quality trends at an upland Welsh site. Hydrol. Process, 10, 183-203.

Robson, A.J., Neal, C., Ryland, G.P. and Harrow, M., 1994. Spatial variations in throughfall chemistry at the small plot scale. $J$. Hydrol., 158, 107-122.

Robson, A., Beven, K. and Neal, C., 1992a. Towards identifying sources of subsurface flow: a comparison of components identified by a physically-based runoff model and those determined by chemical mixing techniques. Hydrol. Process, 6, 199-214. 
Robson, A.J., Neal, C., Smith, C.J. and Hill, S., 1992b. Short term variations in rain and stream water conductivity at a forested site in Mid-Wales -implications for water movement. Sci. Total Environ., 119, 1-18.

Robson, A.J., Neal, C., Hill, S. and Smith, C.J., 1993. Linking variations in short- and medium-term stream chemistry to rainfall inputs - some observations at Plynlimon, Mid-Wales. $J$. Hydrol., 144, 291-310.

Robson, A.J., Neal, C. and Beven, K.J., 1995. Linking mixing techniques to a hydrological framework-an upland application. In Solute Processes in Catchment Systems (Ed. S. Trudgill), Wiley, Chichester, UK, Chapter 13, 347-369.

Taugbøl, G. and Neal, C., 1993. Soil and stream water chemistry variations in acidic soils. Application of a cation exchange and mixing model at the catchment level. Sci. Total Environ., 149, $83-95$.
Wilkinson, R.J., Reynolds, B., Neal, C., Hill, S., Neal, M. and Harrow, M.L., 1997. Major, Minor and trace element composition of cloud water and rain water at Plynlimon, MidWales. Hydrol. Earth Syst. Sci., 1, 557-570.

Worrall, F., Harriman, R., Evans, C.D., Watts, C., Adamson, J., Neal, C., Tipping, E., Burt, T.P., Grieve, I., Monteith, D., Naden, P.S. and Reynolds, B., 2004a. Review of riverine DOC trends in the UK. Hydrol. Process, in press.

Worrall, F., Burt, T.P. and Adamson, J., 2004b. Can climate change explain increases in DOC flux from upland peat catchments? Sci. Total Environ., in press. 